\title{
The Passing of Jean Baudrillard
}

\author{
Robert J. Antonio
}

"I do not have an historical perception of events ... I tend to mythologize.“ Baudrillard [1]

The nearly simultaneous deaths of Ingmar Bergman and Michelangelo Antonioni, in summer 2007, were said to mark the end of an era. The same could be said about the passing of Jean Baudrillard that year. His works engaged and manifested the deep tensions between the troubled path of post-World War Two era modernization and its optimistic mantra of science, growth, and progress. Some of the greatest films of the two directors did the same. Baudrillard belonged to a generation of intellectuals who began their work during postwar modernization's high tide, shifted gears when its fortunes sank, and completed their efforts when its revived, globalized, neoliberal version showed signs of erosion and even meltdown. Jean Baudrillard was a key figure in that ill-defined, many-sided, contested domain of "postmodernist" theory, which he once seemed to embrace and later rejected.[2]

In the 1980s and early 1990s, "postmodernism" became a catchword for a melange of politically ambiguous positions in cultural wars over relativism, rationality, science, multiculturalism, and the classical canon of western thought. Embroiled in these battles Baudrillard was a new sort of public intellectual,[3] who gained celebrity status in a "postmodern" context of new media, new means of cultural distribution, and new class fragments, with increased appetites for culture and theory. Consequently, it is not surprising that his passing was covered about as widely by the media as the deaths of the two famed directors. Baudrillard represents divergent, contradictory threads of the "postmodern" moment. His death, after that of his senior poststructuralist colleagues, mark this moment's ending.

Baudrillard was born in Reims, France. He says that he came from a family of peasant origins and was the first to pursue higher education. He translated German philosophical and literary works and was a teacher at a provincial, French lyceé. Baudrillard later became Henri Lefebvre's assistant at the University of Paris-Nanterre and began to teach sociology there in 1966 after completing his doctoral studies. He was a critic of the Algerian and Vietnam wars, and he identified with the segment of the French left who sought radical, cultural alternatives to official Marxism and Eurocommunism. [4] Nanterre was a center of student radicalism and of the May '68 student-worker protests. The soon after right-turn in France, Soviet invasion of Czechoslovakia, US-China accord, decline of student radicalism, European radical-left terrorism, and other events deflated the high hopes of the generation of '68. Baudrillard's "postmodern" drift from the left bore the imprint of this climate of defeat.

Baudrillard belonged to the important, postwar wave of French poststructuralist theorists (e.g., Foucault, Lyotard, Guattari, Deleuze, Derrida) who exerted major formative influences on "postmodernist" thought and expression. Allan Bloom railed against these thinkers for infecting the U.S. with a French-accented, Germanic bacillus (Nietzsche-Heidegger fusion) that spread "cultural relativism," made the West "just another culture," and appealed to America's "worst instincts" -- justifying already slackened traditional beliefs and discipline and, thus, threatening to derail, in advance, a hoped for post-Cold War era, "American moment in world history." [5] Left-leaning and liberal critics also warned about the dire consequences of "postmodernist" relativism.[6] Baudrillard was not nearly as luminous or feared a French intellectual, as Foucault or Derrida, but he was still one of the most characteristic figures of the postmodern moment. His work is hard to categorize; it is politically ambiguous, often obscure, and plural (he employed cultural, philosophical, literary, and artistic expression). However, when taken seriously, his work radically subverts core Enlightenment presuppositions of liberal-democratic culture, and manifests the extreme "relativism" and "nihilism" that critics of postmodernism decried. Yet other thinkers argue that he employed hyperbole and 
tongue-in-cheek strategies to nudge or upset oblivious attitudes about the severe erosion of democratic culture.

On Baudrillard's March 6th passing, Eurozine stated: "Now the last of the great French philosophers of the 1970s is dead..." [7] The French Minister of Education declared that France had lost a "great creator" and one of its "great figures of... sociological thought" (International Herald Tribune 2007). Identifying Baudrillard as a "sociologist and philosopher," the French newspaper that once regularly published his columns, Libération (2007) said that his radical criticism of consumer society and the media had been suffused with "dark humor" and "joyous pessimism." Regardless of the French kudos, Baudrillard was a more important figure in English-speaking nations than at home. The New York Times asserted that he was a "postmodern guru," but that he was "too original and idiosyncratic" to fit neatly any political or theoretical category. It described Baudrillard as a: "French critic and provocateur... whose theories about consumer culture and the manufactured nature of reality were intensely discussed both in rarefied philosophical circles and in blockbuster movies like 'The Matrix'..." Although he wrote for newspapers, said The New York Times, he generally "shunned the media" that were the central focus of his works (Cohen 2007). Others also reported that he did not watch TV and was hesitant about digital technologies.

Calling Baudrillard a "cult figure," The Times (2007) of London said that he had diverse interests in photography, art, film, and poetry and influenced many artists and writers. It quoted novelist J.G. Ballard's claim that he "was the most important French thinker of the last twenty years." The Los Angeles Times also reported his impact on popular culture and on Jeff Koons, Haim Steinbach, Robert Longo, and Peter Nagy (Woo 2007). But the obits do not explain how closely readers attended to his ideas or how they employed them in their work. Baudrillard's critics say that his "influence" merely manifested his celebrity and superficial fascination with his provocative terms and images. They argue that one can glean only from the surface of his work, because that is all there is to it. It has no depth they say! Baudrillardians shrug. They imply that the philosopher's simulation of depthless, media culture both reveals and resists hyperrealty.

Most obits mentioned Baudrillard's ideas of simulation and hyperreality and reported his impact on Andy and Larry Wachowski's popular Matrix films and the 1999 opener's reference to him. The movie's central figure Neo opens a hollowed out, or simulated copy of Baudrillard's Simulacra and Simulation in which contraband computer discs are hidden.[8] The Wachowskis reportedly had the actors read his work to prepare for their performances. Baudrillard held that the directors attempted to contact him, after the first film, seeking his involvement in the sequels. However, he did not take up their offer. He said that The Matrix's Platonist thrust contradicted his idea of a realer than real hyperreality, which is exclusively surface, not a counterfeit image of an underlying reality, and is governed by a self-reproducing aleatory logic, not by a rational plot of a mindful elite.[9] Referring to the Matrix controversy, the Los Angeles Times said that: "Its false representation of a theory about false representation made the irony dizzyingly complete"(Woo 2007). Baudrillard was already a celebrity intellectual prior to The Matrix, but the movie enhanced his cult status. Unsurprisingly, Simulacra and Simulation (1994a) is by far his best selling text at Amazon.com, possibly manifesting the depthless, "postmodern" culture portrayed in the essays.

Baudrillard retired from his academic post at Nanterre in 1987, leaving more time for his creative efforts, travel, and public activities. He started writing regular columns for Libération, which he continued doing for a decade. In the 1990s, he worked the California lecture circuit and other major venues elsewhere. Several obits mentioned his Las Vegas area, poetry reading at Whiskey Pete's as if it were a prototypical Baudrillardian event; he performed bedecked in a gold lamé suit, accompanied by a cool band. The performance was later released on CD - Suicide Moi. Prospect's Marina Benjamin (1997) described his celebrity prior to its post-Matrix peak: “'I em nouthing,' Jean Baudrillard informed me, throwing his hands into the air in emphatic accompaniment. Thousands would disagree. Currently France's most successful intellectual export, this retired sociologist turned philosopher causes a stir wherever he goes. Last year, tickets to hear him expound his philosophy of disappearance at the Institute of Contemporary Arts were like gold dust. Hundreds of fans queued in vain for returns, and one distraught young man threatened to kill himself if he was not let in. A few weeks ago, after a whirlwind tour of Brazil, Baudrillard returned to the ICA to kick off its 'Big Thinkers' talks which sold out in four hours flat."

In a 2005 reading at New York's Tilton Gallery, richly described by The New Yorker's Larissa MacFarquhar, Baudrillard told the ultrahip art crowd that simulation's suffusion of art throughout the culture has destroyed its transcendent quality and is "the very end of art."[10] MacFarquhar summed up succinctly his US tour: "he is still going about his usual French Philosopher business, scandalizing audiences with the grandiloquent sweep of his gnomic pronouncements and post-Marxian pessimism." Asked for information about himself after the Tilton Gallery lecture, he declared: "I am a simulacrum of myself." Commentators pose or imply the question: "Is he for 
real?" Only his ardent followers and severe critics are sure they know.

Many obit heads played humorously on the simulation theme: "Baudrillard's simulacrum died"; "The Shadow of His Former Self”;"Has this Man Really Died?”;“Reality claims Gallic Provocateur”; "Reports of Jean Baudrillard's Death are Somewhat Exaggerated"; and "Kept a Sharp Eye on Blurry Reality." Reuters (2007) held that he had "a mordant sense of humor," and more than one commentator called him a "philosopher clown." Reporting the nearly simultaneous passing of Baudrillard and the cartoon character "Captain America," The Daily Telegraph's head read: "One of These Comic Heros is Really Dead" (Leith 2007). Baudrillard's penchant for ironic, hyperbolic one-liners was the bane of humorless interviewers,[11] but his genial, lighthearted, unpretentious ways won over most interlocutors. Professing love for and fascination with America, he saved some of his best comedic lines for the narratives about his travels here; Disneyland is the "real" America," California is the "absolute simulacrum," and the US is an "(un)culture" and "the only remaining primitive society." [12] His call to resist simulation's oppressive cultural control system by practicing greater "indifference" than our "silent majorities" was also a howler.[13]

However, Baudrillard's view of the US as a banal, obscene "utopia achieved" was not really tongue-in-cheek and surely not universally appreciated.[14] A few obits mentioned his attack on Susan Sontag's charitable intentions, during the Bosnian War, which led her to countercharge that he was "a political idiot," possibly a "moral idiot," and surely "ignorant and cynical." [15] Other activist critics have posed similar charges about his advocacy of indifference. Several obits admonished him for his controversial views about war, 9/11, and globalization.[16] Reuters'(2007) said that his The Gulf War Did Not Take Place (1995) typified his "provocative, paradoxical style" and that his 9/11 views displayed "a lack of sympathy for the victims." The Times (2007) of London said that his Gulf War book illustrated "the virtualization of western culture," but called the work "notorious." Many critics saw his views on such matters to be insightful, but in poor taste. By contrast, supporters insist that his bitingly ironic style was the secret of his critical edge.

Slate declared that "Baudrillard's grotesque allure" was "his willingness to go to an inhumane extreme to make a surgical strike on your consciousness," but that this tendency made his work hard to grasp. "To quote him is to misquote him": said Slate (Agger 2007). Others have described his works as "obscure," "fragmented," "dense" "illusive," or even "meaningless." By contrast, Baudrillardians usually have held that his difficult, often impenetrable style was the chief vehicle for his creativity and insight. Chris Turner (2007) repeated one of his oft quoted lines: "the world was given to us as enigmatic and unintelligible, and the task of thought is to make it, if possible, even more enigmatic and unintelligible." Like early twentieth century avant-garde artists and literary modernists, Turner argued, Baudrillard employed enigma with the intent of radically transforming art and politics. Turner implied that his works had the desired effect in some circles. Arthur Kroker (2007) spoke glowingly of how Baudrillard "made thought itself a faithful illusion of the sorcery of hyperreality." He claimed that Baudrillard's "cultural theory of simulation ran parallel to the great scientific discoveries of our time..." and that the philosopher laid bare "the secret of reality itself." By "refusing to be simply culturally mimetic," he argued, Baudrillard "actually became a complex sign of the social reality of the postmodern century."

Science-oriented critics also contended that Baudrillard was a prime representative of the "postmodern" moment, but they equated his work and "postmodernism" overall with rank irrationalism. In their view, he was the prototype "postmodernist" relativist - as exposed in the "science wars" ignited by the Social Text affair.[17] The Los Angeles Times quoted scientists, Alan Sokal's and John Bricmont's gibe - "Baudrillard's texts seem unintelligible" because "they mean precisely nothing." [18] The two physicists contended that his abuse of scientific concepts, frequent employment of neologisms and unsupported generalizations, and carefree attitude about details epitomize "postmodernism's" "fashionable nonsense" and "intellectual quackery." Other critics charged that this "seductive unreason," combined with his "political fatalism," feeds "reactionary" cultural and political currents (Wolin 2004, p. 306). Back-to-back Amazon.com reviews of his Baudrillard’s Gulf War book typify the extremely polarized opinions about his work: "profound error and transcendent stupidity, the most inane ever reviewed" versus a "brilliant" piece of "pure sociological poetry." The Economist (2007) obit said that his ideas may be "utter nonsense" or "profound critique," but, in either case, they are provocative. His ardent critics and followers agree that, for better or worse, his ideas subvert western beliefs in science, rationality, and truth.

Theorists associated with the journal Telos were among the first thinkers in North America to engage Baudrillard's theories. Telos Press published the first English translations of his books -Mirror of Production ([1972] 1975) and For a Political Economy of the Sign ([1973] 1981). In these works, Baudrillard attacked Marx's labor theory of value and materialism and framed an alternative cultural theory, stressing symbolic exchange and sign- 
value. He undercut Marx's and the Hegelian left's "historicist" method of immanent criticism, or ideology critique. [19] This decisive move was the basis for Baudrillard's apocalyptic, declinest "end of ideology" and "end of history" arguments, which pervade and constitute the core thrust of his mature work.[20] Also, seeking alternatives to Marxism and the postwar left, Telos revived the Frankfurt School's deeply pessimistic "dialectic of Enlightenment" and "one-dimensionality" arguments, which also departed left historicism, drew heavily from Nietzsche and other critics of Enlightenment, and saw mid-twentieth century, liberal democracies to be "totally administered societies." In a nutshell, they argued that the historical resources for critique and emancipation had been neutralized by mass culture and mass politics. The Telos circle engaged these earlier views, but stressed that the quiescent state of late1970s, U.S. politics derived from the left's integration into welfare state and consequent illusion that the system was responsive to criticism (making it all the more resistant to political transformation). Although concurring that the left was moribund, Baudrillard portrayed a much more fundamental exhaustion; evaporation of the cultural bases of reciprocal, meaningful exchanges between interlocutors and annihilation of the media needed to inform a deliberative democratic citizenry. In the books published by Telos Press, he substituted a "simulation model" for the democratic left's and modern social theory's communication model; he held that semiotic codes homogenize and regiment so thoroughly that they preclude delivery and reception of the types of information necessary for collective agency and genuinely democratic politics.[21]

English translations of Baudrillard's more emphatically "postmodernist" works, which elaborated the ideas of simulation and hyperreality and did not look back to Marx and to critical theory, were published while Thatcherism and Reaganism flourished and left-liberal politics seemed moribund. His Simulations (1983a), In the Shadow of the Silent Majorities (1983b), and The Ecstasy of Communication (1988) were much more widely read and debated than the texts published by Telos Press. He argued that simulation, or the capacity to create identical copies from models, turns culture into a flat surface, radically homogenizes and dehistoricizes it, and neutralizes critical distance, or the capacity to stand back, evaluate, and criticize; face pressed against the screen, "seduction" and "fascination" rule. Baudrillard held that simulation "pushes us... close to psychosis"and that only "indifference," or a refusal of meaning, could upset the symbolic exchange process that animates the simulation system.[22] At the end of the 1980s, he declared that the world was in "anorexic ruins" and that: "everything that was swept away in "68 is now restored...”(Baudrillard 1989:43). His extreme, digital version of one-dimensionality universalized the wrecked hopes of "68ers and resonated with dystopian themes in the popular culture of that time (expressed classically in Blade Runner) and in new versions of end of ideology discourses (e.g., "end of history," end of left and right," "end of alternatives"), which proliferated in the later 1980s and early 1990s. However, Baudrillard's tone was not one of panic, but suggested the attitude of a relatively untroubled, fascinated bystander. He ranged widely and speculated philosophically, during the1990s, but did not reverse his "postmodernist" course.[23]

During Baudrillard's later years, globalization supplanted postmodernism as the big transdisciplinary discourse and battles over it suffused the public sphere. Francis Fukuyama's and Thomas L. Friedman's bestsellers, advocating neoliberal globalization, implied that the process revived modernization by relieving capitalism of its burdensome postwar, social democratic baggage and making it more vibrant, efficient, and expansive.[24] Neoliberals held that Reagan era, U.S. economic restructuring ignited globalization; it brought down regulatory barriers to free trade, stemmed the postwar socialist tide, and advanced freedom, growth, and progress. They also held that Reagan's military build-up won the Cold War, opening the world to free-market capitalism and making the US the globalization system's lone superpower or “benign hegemon.” American leadership in the first Gulf War, President Clinton's embrace of neoliberal globalization, and the roaring ' 90 s stock market seemed to realize the economic and geopolitical hopes of Reaganism.

Contra neoliberalism, Baudrillard saw US-led globalization to be a "reversion of history" that radically intensified and extended cultural homogenization, produced major fragmentation and dislocation, and generated profound resentment of American power. Countering left-leaning critics, who advocated opposing or regulating the process, he argued that the "antiglobalization movement" and "positive alternatives" can neither reform globalization nor slow its liquidation of particularity. He contended that only "singularities," or one-time (i.e., "incomparable, irreducible, inexchangeable") "events" can upset cultural homogenization's logic of equivalence, and, thus, undermine globalization. [25] Although not all singularities are violent, he explained, terrorism is an "insurrectionary singularity" that inheres in globalization and threatens the process.[26] Baudrillard called 9/11 a "irreducible singularity" and "mother of all events," signifying Americans being “overtaken by their own power." He argued that 9/11's disruptive force did not derive from the violence per se, but from its "symbolic violence"; the strikes on the Twin Towers and 
Pentagon, chief symbols of American economic and geopolitical power, humiliated the United States and exposed its vulnerability.[27] His assertion that the attacks were a response to "insufferable," U.S. hyperpower led to charges that he justified terrorism, which he vigorously denied. Still his argument that terrorism resists homogenization and globalization processes and that it could unravel them and the entire simulation system implies, at least, indirect sympathy for the attackers' aims.[28] "After history," Baudrillard declared, "ruptural events," like 9/11, "appear no longer the bearers of constructive disorder, but of absolute disorder.' [29] In his view, terrorism reintroduces negativity, but promises only disintegration of western modernity and its Enlightenment ideals, not revolutionary progress. However, Baudrillard implied that a new order based on premodern, symbolic exchange and myth, which he preferred, could arise spontaneously from the cultural wreckage.[30]

Baudrillard's emphasis on profound political and cultural exhaustion pervades his views of globalization, terror, and $9 / 11$ and is the leitmotif of his overall corpus. He declared himself to be a Nietzschean, but his vision of radically flattened hyperreality precludes Nietzsche's hopes for aesthetic transcendence, creation of new values, and sovereign individuals. [31] If the scenario of a self-reproducing, all-dominating simulation system is truly the "reality" of our time then Kroker's claim that Baudrillard "completed Nietzsche" might be plausible.[32] However, more likely, he recycled and extended imaginatively, Heidegger's claims about total technological domination and consequent cultural homogenization and dehumanization. Its not surprising that the Baudrillardian, Kroker saw "Heidegger to be the theorist par excellence of the digital future"; he might have detected this theme, which seems hard to miss, to be a subtext of Baudrillard's works. [33] Heidegger's argument about a "darkening of the world"- sweeping cultural exhaustion and loss of collective agency, driven by technological rationalization - was so extreme that it made a mockery of liberal democracy and, arguably, helped create the cultural and political climate for Weimar-era "revolution from the right" and fascism. Although delivered in a mild-mannered and often jocular tone, Baudrillard's argument about postmodern homogenization-regimentation suggests even more profound exhaustion, completely barren of historical resources for change. He was dismissive of the liberal-democratic legal, political, and cultural institutions that he took-for-granted in everyday affairs and that made his work and good life possible.[34] What is left for us if we accept his assertion that we live in a world order "exclusive of all ideology" and, consequently, where "all the objectives of the Enlightenment are lost"(Baudrillard 2006b:8)? Should we "abandon all hope?" Baudrillard's antihistoricism, tacit antiliberalism, and stress on fascination and mythology have highly ambiguous political directions and may have, as some critics argue, an affinity for reactionary tendencies. Regardless, his antiEnlightenment views lose critical force in the face of the nearly worldwide wave of culturally repressive and violent fundamentalism and neopopulism, which he cautioned us not to berate, less we ignore their role as "singularities."

Many commentators charge or imply that Baudrillard was a bullshit artist. Philosopher, Harry G. Frankfurt holds that "bullshit" is unavoidable, when we hold forth on matters that we know little or nothing about and that the consequent gap between "opinion" and "apprehension of reality" is "relatively" more common today than before. [35] Indeed, he implies that "bullshit" suffuses our public discourses today. Frankfurt argues that "bullshitters," by contrast to liars, do not try to conceal "truths," but they improvise, color, and expound without constraint. He says that "bullshitters" may, by chance or intuition, occasionally get things right, but, because they put aside the "authority of truth" completely, they are ultimately its greater enemy.[36] Frankfurt holds that they act as if they know, when they don't know at all; they hide the fact that they are totally unconcerned with the "truth-values" of what they say. [37] Baudrillard did not dissemble in this way! His often humorous, transparently hyperbolic claims, and playful admission, at some points, that his ideas are bullshit suggest an ironic "story-teller," who entertains and unveils, rather than "bullshits." Good story-tellers often generate moral and emotional distance, allowing us to see things in a different, problematic light. Some commentators claim that Baudrillard did just that.

However, Frankfurt also contends that the "deeper sources” of today's "proliferation of bullshit" are "“antirealist' doctrines," which deny "objective realities" so decisively that they discourage diligent, honest inquiry and speech in matters that call for close attention and prudence (e.g., climate change) (Frankfurt 2004:64-5). If we accept this view, then Baudrillard must have encouraged "bullshitting," even if he did not regularly practice it. He and other "academic," radical epistemic relativists likely have fueled and legitimated, at least, in some circles, the profusion of "bullshit" and consequent irresponsibility and failure to face realities, problems, and crises. Still their ideas are primarily manifestations of the "bullshit" problem, not chief causes of it. Critics' claims about the grave cultural damages inflicted by "postmodernists" overstate their reach. Better situated talking heads, pundits, PR people in the political and business classes, religious and political leaders, and others, who honed their "bullshitting" skills in the heat of big public battles over material and ideal interests, have been much more active, influential purveyors of 
"bullshit." And these individuals were the main targets of Frankfurt's little broadside. They did not need Baudrillard or any philosophical props to operate, and the ones who sought legitimation often borrowed from Bloom and other defenders of the Truth. Yet radical perspectivists and absolutists feed off each other, and together manifest the cultural crisis Baudrillard is a sign of.

The prevalence of PR, political spin, and tabloid news seemed to be in rapid ascent in the 1980s, when the convergence of ideological, political, regulatory, and technical changes opened the way for the profusion of "bullshit." Baudrillard saw the Reagan Presidency to be a watershed moment; he held that President Reagan personified the hyperreal California heartland, where the line between the media and rest of culture had been elided. Baudrillard stated that: "In the image of Reagan, the whole of America has become Californian. Ex-actor and ex-governor that he is, he has worked up his euphoric, cinematic, extraverted, advertising version of artificial paradises of the West to all American dimensions" (Baudrillard 1989b:108). Baudrillard's views do not seem all that hyperbolic in light of Reagan's occasional confusion of cinematic events with actual ones and his other gaffs, such as his declaration, in a 1984 presidential debate with former Vice President Mondale, that he would share Strategic Defense Initiative (Star Wars) technologies with the USSR.[38] His plan for the United States to spend many billions of dollars on SDI technology and then give it to the regime that he called the "evil empire" seemed to be an absurd proposal, but it stirred little controversy. The headline-grabbing phrase in presidential politics that year was Mondale's earlier use of a Wendy's Hamburger advertisement - "Where's the beef?" - to belittle presidential primary, candidate Senator Gary Hart, who was later done-in by very well-publicized tabloid stories about his affair with Donna Rice.[39] How Baudrillardian! President Reagan's problematic moments did not derail his re-election, or upset the vision of him as the "Great Communicator." When the mainstream press noted his gaffs, they treated them in a humorous way that did not question his capacity to act as the "leader of the free world" and keeper of SDI technology.[40]

The media has not been quite as kind to presidents that came after Reagan and after the inception of Internet and suffusion of all-day tabloid "news" and talk radio. In the various camps, Rove-like figures design and command virtual wars that would make Neo shutter. The media spectacle surrounding Monicagate and the swift boat battles contain vintage Baudrillardian moments. President Bush posing in pilot's gear and speechifying about the end of major combat in Iraq, on the deck of the USS Abraham Lincoln, is an iconic image that has generated much backwash. Failing to learn from Bush's debacle, John Kerry saluted, played soldier, and "reported for duty" at the Democratic Convention and later drowned in the backwash. These types of virtual events with real consequences crossed my mind while writing this essay - the print and TV images of the bogus claims about WMDs and Saddam's involvement in 9/11, Jessica Lynch and Pat Tillman hoaxes, cropped videos of the toppling of Saddam's statue, blatant lies about torture and rendition, Alberto Gonzales' poor memory, ad infinitum. An obit writer said that Baudrillard employed "rhetorical exaggeration" to "engage with the real world" critically.[41] Another obit writer asserted that: "The 1990 Gulf war was modeled by planners using simulations; it was won, if we call a massacre a victory, largely by pilots looking at computer screens; and it was relayed to the public by television. Most consumers of these images get no reality check; the image is all we have to go on. And the image does not come to us innocently" (Blackburn 2007). Baudrillard draws attention to the rampant political spin, obsession with celebrity, and eroded line between entertainment, news, politics, and life.[42] Even if "postmodern," media culture is not always realer than real, his ideas still bring it into view and stir critical thought about its qualities and profusion.

Generous readers and interpreters of Baudrillard imply that his extreme moves generate the critical distance that he held had been evaporated by the anesthetized, entertainment and media stupor that he described so richly. They imply that he alerts us to suffusion of "bullshit," and exposes the mechanisms that deliver it. Others say that Baudrillard sensitizes us to the creative possibilities of digital technologies and new media, and inspires fresh work in the arts and popular culture, which belies his claims about the end of art. But these views can be turned round by critics, who assert that his indifference, hyperbole, and careless ways affirm the neutralized critical sensibilities and political torpor that he also portrayed so well and seemed to celebrate. Others charge that his anti-Enlightenment views feed reactionary sensibilities. Still others contend that his hyperbolic claims illuminate the most media-thick and entertainment-thick public spheres, but cast a shadow over the rest of culture and hide the animate social worlds extending beyond the simulated ones. Perhaps his totalizing argument about hyperreality is a self-referential reflection of his celebrity that constricts his vision, but, focusing it narrowly, provides a productive one-sidedness. And maybe all these divergent perspectives about the philosopher have some veracity.

Like Nietzsche, Baudrillard did not seem troubled about his contradictions and likely thought, in Nietzschean fashion, that they catch attention, provoke rumination, and, thereby, are indeed productive. Many commentators 
portray him as a provocateur; an accurate characterization I believe. However, Kroker's claim that Baudrillard was "a complex sign of the social reality" of his times might be an even better way to remember him - a multisided, imaginative, and free-wheeling thinker, who mirrored his "postmodern" moment's creative forces and contradictions and pointed beyond them to the next historical conjuncture when the bullet hits the bone.

\section{Endnotes}

1. Asked about postmodernism, Baudrillard said: "I have nothing to do with it. I don't know who came up with the term... But I have no faith in 'postmodernism' as an analytical term. When people say: 'you are a postmodernist,' I answer: 'Well why not?' The term simply avoids the issue itself." He declared that he was a "nihilist, not a postmodernist." (Baudrillard and Lie 2007:3-4). However, he had earlier defined "postmodernism," employed the concept, and implied that he was "postmodernist" (e.g., Baudrillard 1989a).

2. See Donadio 2007, for a retrospective on the culture wars in the wake of Bloom's intervention.

3. One British survey asked more than 20,000 people to rank one-hundred leading public intellectuals; Baudrillard placed twenty-second (lodged between Francis Fukuyama and Slavoj Zizek) (Herman 2005). In my search of The New York Times electronic archives (1981-August 2007), Baudrillard appeared in 79 articles.

4. Young Baudrillard was influenced by Henri Lefebvre, Roland Barthes, Guy Debord and the Situationalist International and other left-leaning thinkers, beginning to entertain new forms of cultural expression, control, critique, and resistence. See Kellner 1989; 2005a; 2005b; 2006; 2007 for comprehensive analyses of Baudrillard's thought in its various phases and contexts.

5. Bloom argued that later twentieth century, American leftists found Marx "boring," switching allegiance, via the new French cultural theories, to Nietzsche and Heidegger (with a significant infusion of Freud and Weber). He held that this shift magnified the cultural relativism and anti-Western themes already prominent in Marxism. See Bloom 1987, pp. 38-39, 141-56, 194-97, 217-26, 374-82.

6. See Wolin 1990; 2004, for parallel left-liberal criticism, stressing the Nietzsche-Heidegger fusion. Other left-liberal thinkers, like Todd Gitlin (1995), blamed "postmodernism" and the type of left-wing, identity politics that it allegedly justified for providing ammunition to Bloom and others, who helped engineer the neoconservative right-turn.

7. Lie in Baudrillard and Lie (2007:1).

8. The character, Neo, discovers that reality is an illusion and leads battles against the artificial intelligence, or machines, that created the virtual world and exploited humans as a power source.
9. By contrast, The Matrix's Neo and his allies lay bare the grim reality beneath the virtual world, and discover that it is planned and governed rationally by repressive conspirators. While Baudrillard argued emphatically that active resistance only fortifies hyperreality, Neo and friends waged a good war against the machines and their virtual reality. See Baudrillard 2004a.

10. MacFarquhar (2005) said: "The audience was too big for the room - some people had to stand. A tall, Nico-esque blond woman in a shiny white raincoat leaned against the mantelpiece, next to a tall man with chest-length dreadlocks. A middle-aged woman with read-and-purple hair sat nearby. There was a brief opening act: Arto Lindsey, the one-time Lounge Lizard, whose broad forehead, seventies style eyeglasses, and sturdy teeth seemed precariously supported by his reedy frame, played a thunderous cadenza on a paleblue electric guitar." Baudrillard (e.g., 1983a: 150-52) framed his ideas about the end of art decades before this gathering.

11. Baudrillard was unflappable while answering New York Times notoriously, sarcastic Deborah Solomon's (2005) questions: "Are you saying that America Represents the ideal democracy?"; "So you don't think that the US invaded Iraq to spread freedom?"; "Isn't that kind of simplistic reasoning why people get so tired of French Intellectuals?" Baudrillard answered, straight-faced in short, cutting, ironic phrases. The tongue-in-cheek facets of Baudrillard's comments are, in some ways, reminiscent (although less sarcastic) of young Bob Dylan's famous exchanges with naive, overly eager reporters or baseball announcer, Joe Garagiola's (who was standing in for Johnny Carson) hilarious exchange with guests, John Lennon and Paul McCartney.

12. Baudrillard 1983a, pp. 24-6; 1989, pp. 7, 126, 128.

13. Baudrillard held that "hyperconformist simulation" is the only way to resist the simulation system. See Baudrillard 1983b, pp. 12-14, 41-61, 95-110; 1988, pp. 97-101.

14. Baudrillard (1989b:27-9) said: "I ask of the Americans only that they be Americans. I do not ask them to be intelligent, sensible, original." In his view, we live entirely on the surface, without reflection, subtlety, nuance, or wile, providing the outside observer "the opportunity to be so brutally naive." $\mathrm{He}$ held that Americans "are themselves simulation 
in its most developed state," and, lacking depth, we are completely unaware of the process and condition. However, Baudrillard also quipped that France was merely "a copy with subtitles"(quoted in Harkin 2007).

15. Sontag was responding to Baudrillard's sharply critical comments about her directing Beckett's Waiting For Godot in Sarajevo, while it was under bombardment by the Serbs. He criticized her "condescending manner," and implied that she served the imperial aspirations of George H.W. Bush's "New World Order"(Baudrillard 1994b; Coulter 2005; Chan 2001).

16. For a highly critical perspective on Baudrillard's views of the US and on 9/11, see Wolin 2002; 2004: 30106.

17. The "science wars" followed in the wake of the publication (in the cultural studies journal, Social Text) of Alan Sokal's hilarious, totally bogus, postmodern physics article, rife with "postmodernist" jargon and genuflections to famous "postmodernist" theorists. The editors apparently took the parody seriously and accepted it without review by science-competent referees. By contrast to Allan Bloom, Sokal (1996) identified himself as a leftist and feminist and "on the same side as the Social Text editors." However, he thought that "postmodernist," cultural studies was bankrupt intellectually and an unhelpful distraction politically. For numerous links to materials from the international debate following this affair go to http:// physics.nyu.edu/ as $2 /$.

18. Woo (2007) quotes from Sokal and Bricmont, Fashionable Nonsense (1998), which addresses the Social Text affair and alleged postmodernist "abuse of science."

19. Marx claimed that "socially necessary labor time," hidden beneath the surface of fluctuating prices, determines the ratios by which commodities exchange and that extraction by means of the unequal wage relationship between labor and capital, obscured by liberalism's claims about voluntary contracts and supply and demand, is the basis of capitalist accumulation. Baudrillard rejected Marx's "labor theory of value"and all other "depth models," which see the cultural surface of signifiers and images to be an ideological distortion of "real" determinants or operant forces "below," which can be laid bare by scientific inquiry and ideology critique. Beaudrillard's argument that "postmodern" culture neutralizes the social bases of these methods is at the heart of his one-dimensionality thesis and simulation model. Overall, Marx and his followers contended that emancipatory possibilities are nestled within capitalist modernization and refracted in liberaldemocratic ideology. Holding that capitalist inequality and oppression contradict the promises of equality, freedom, and plenty, Marx and his fellow travelers identified new structural and cultural conditions and possibilities that favored realization of universalized, radicalized versions of liberal ideals and pointed to an emergent collective agent, the revolutionary working class, that they hoped would make the radicalized ideals governing norms. Liberal-democratic and social democratic modernization theories offer parallel nonrevolutionary accounts of modern capitalist development containing seeds of progress and fresh means to refine and advance democratic institutions (more gradually realized through immanent critique, collective action, and planning).

20. Baudrillard claimed to reject apocalyptic perspectives, but his vision of exceptional cultural and political exhaustion of liberal-democratic culture suggests just such an approach.

21. By contrast to Baudrillard, the Telos circle's critique of the American left's "artificial negativity" was animated by their search for "organic negativity,"or new sources of collective action and radical politics. However, their theoretical moves, like that of the Baudrillard, had ambiguous, contradictory, political directions.

22. Baudrillard (1983a:109, 152) said that "the order of signifieds" becomes "the play of infinitesimal signifiers, reduced to their aleatory commutation. All transcendent finalities reduced to a dashboard full of instruments." He said the flow of signs induces "schizophrenic vertigo."

23. See Baudrillard 2002a, for essays that express the directions of his 1990s thought.

24. See Fukuyama 1992; Friedman 2000.

25. Baudrillard (1989:41) had earlier argued that the "postmodern" moment was devoid of "events," but that "surprise" could come from "a new event" impossible to anticipate on the basis of earlier history. Later, he claimed that 9/11 was just such an event.

26. Baudrillard (2003:4) held that: “...singularities are neither negative nor positive... Singularities are not alternatives. They represent a different symbolic order. They do not abide by value judgments or political realities. They can be the best or the worst. They cannot be 'regularized' by means of a collective historical action." He added that: "The singularity of terrorism avenges the singularities of those cultures that paid the price of the imposition of a unique power with their own extinction."

27. Baudrillard claimed that the "abject and pornographic" images of the Abu Garib torture had the same, albeit self-inflicted, humiliating impact. His arguments here are rooted in his ideas about symbolic exchange, which he first developed in earlier works. Baudrillard's conception of exchange is based on his engagement with theories about its premodern forms, which valorized the ability "to give back.." See Baudrillard 2001a; 2003; Kellner 2005a. Moreover, Baudrillard first formulated his view of terrorism more than twenty years before $9 / 11$. He held that the World Trade Center's Twin Towers were the "visible sign of the closure of the system," but that random, senseless terrorism escapes this control and poses a major threat 
to established power. His prescient moments puzzled his critics. See Baudrillard 1983a:135-38; 1983b:48-58.

28. Although holding, from the start, that singularities are neither good nor bad, Baudrillard warned critics not to "berate" ethnic, religious, or individual outbursts against globalization and its supporters as "simply populist, archaic, or even terrorist." $\mathrm{He}$ said that such "events" are now "engaged against the abstract universality of the global" (Baudrillard 2003:4).

29. See Baudrillard 2005:8;

30. On themes discussed in the above paragraph, see, Baudrillard 1994c; 2001b; 2002b; 2003; 2004b; 2005; 2006a; 2006b; 2007; Coulter 2004; Kellner 2005b.

31. Nietzsche criticized nihilism, while Baudrillard embraced it. Nietzsche declared that modernity was on the verge of collapse, but he contended that the "good European's" nascent hybridity contained seeds of a new culture and new types of humanity and that a "new order of rank," or life-affirming values could be created by nascent autonomous individuals, who share a creative "will to power," multiperspectival vision, and rich aesthetic sensibilities.

32. Nietzsche did not anticipate these conditions, and they would require new theories.

33. Kroker 2002, p. 1. See Kroker 2004, for more on his views about Heidegger. Baudrillard's arguments about globalization, terror, and, more generally, virtual reality, all stress complete "submission" to technology and total "dependence" on it. The Heideggerian influence on Baudrillard is obvious in his employment of Heidegger's terminology; e.g. that "technological 'enframing"' has instituted total control over the world (Baudrillard 2006b:6). Imported to France in the mid1950s, Heidegger's (e.g., 1977) ideas about technology and homogenization were engaged seriously by the older generation of poststructuralists and were passed on to their students. Moreover, they often engaged Nietzsche's thought via Heidegger.

34. Seeing Enlightenment "juridical and moral superstructure" to be moribund, Baudrillard casually dismissed "human rights" as an "alibi" and "advertising" (2004b:7). He declared that, today, "the concepts of liberty, democracy, and human rights look awful" (2003:3). Similar comments about the exhaustion of democratic culture are spread throughout his works.
35. Frankfurt's On Bullshit (2006) was first published in 1986 as a journal article, while the writer was professing philosophy at Yale. The republication twenty years later as a slim 67 page text had a Baudrillardian twist. Frankfurt was interviewed on The Daily Show and 60 Minutes, discussed on the Blogs and in newspapers, and rose near the top of The New York Times bestseller list. For a brief moment, the philosopher became a celebrity scholar. See Frankfurt's interview about Jon Stewart's and Stephen Colbert's outing of "bullshitters" by ridiculing them (http://www.youtube.com/ watch? $=x-7$ IW8 $\mathrm{CxgXY}$ ).

36. Frankfurt does not imply the Platonic variety of Truths, or absolutes, but the conditional types of warranted knowledge about the world, which we seek in honestly practiced science and in mindful everyday thought and practice, geared to inform or direct prudent action of all sorts. This type of knowledge is based on inquiry, and is open to question, pragmatic tests, and revision. Platonic absolutes are not subject to inquiry, and bullshit puts aside inquiry.

\section{See Frankfurt 2005:55, 61-7.}

38. President Reagan was responding, at least indirectly, to critics, who argued that the Soviet leadership would have been so deeply threatened by the US's defensive missile shield and consequent end of of nuclear parity that they would have been tempted to launch a pre-emptive nuclear attack just prior to the new technology's implementation.

39. The historic photo of the good Senator Hart seaside with Donna Rice on his lap was and iconic image that ranks with Bill Clinton's famous Monica hug.

40. The events concerning Reagan, Mondale, and Hart took place between March and October of 1984. See Baudrillard 1989b:113-4, for speculation about why Reagan's gaffs did not incur political costs.

41. He added that conventional philosophers languished in irrelevant abstraction (Harkin 2007).

42. Even Baudrillard's anti-Enlightenment themes, provoke critical thought - (i.e., they raise questions about the use of liberal ideals to justify employment of massive force and the consequent deaths, injuries, dislocation, and general devastation that follow).

\section{References}

Agger, Michael. 2007. "Le Browser: Saluting Jean Baudrillard." Slate (March 14). (http://www.slate.com)

Baudrillard, Jean. [1973] 1975. The Mirror of Production, trans. Marx Poster. St. Louis: Telos Press
[1972] 1981. For a Critique of the Political Economy of the Sign, trans Charles Levin. St. Louis: Telos Press

1983a. Simulations, trans. Paul Foss, Paul Patton, and Phillip Beitchman. New York: Semiotext(e) 
.1983b. In the Shadow of the Silent Majorities, or, The End of the Social and Other Essays, trans. Paul Foss, John Johnston, and Paul Patton. New York: Semiotext(e)

1988. The Ecstasy of Communication, trans. Bernard and Caroline Schutze. New York: Semiotext(e)

1989a. "The Anorexic Ruins." Pp 29-45 in Looking Back at the End of the World, Edited by Dietmar Kamper and Christoph Wulf. Trans. David Antal. New York: Semiotext(e)

[1986] 1989b. America, trans. Chris Turner. London and New York.: Verso

1994a. Simulacra and Simulation, trans. Sheila Faria Glaser. Ann Arbor: University of Michigan

. 1994b. "No Reprieve for Sarajevo."Libération (January 8). (http://www.egs.edu/faculty/baudrillard)

. 1994c. "Reversion in History." CTheory. (http://www. ctheory.net)

. 1995. The Gulf War Did Not Take Place, trans. Paul Patten, Bloomington: Indiana University Press

.2001a. Impossible Exchange," trans. Chris Turner. London and New York: Verso.

. 2001b. "The Spirit of Terrorism." European Graduate School Faculty (http://www.egs.edu)

2002a. Screened Out," trans. Chris Turner. London and New York: Verso.

.2002b. The Spirit of Terrorism," trans. Chris Turner. New York: W.W. Norton

2003. “The Violence of the Global." CTheory. (http:// www.ctheory.net)

2004a. "The Matrix Decoded: Le Nouvel Observateur Interview with Jean Baudrillard. International Journal of Baudrillard Studies (July). (http://www.ubishops.ca/ BaudrillardStudies)

2004b.”This is the Fourth World War. The Der Spiegel Interview with Jean Baudrillard. International Journal of Baudrillard Studies (January). (http://www.ubishops.ca/ BaudrillardStudies)

2005. "War Porn." International Journal of Baudrillard Studies (January). (http://www.ubishops.ca/ BaudrillardStudies)

. 2006a. "Our Society's Judgement and Punishment." International Journal of Baudrillard Studies (July). (http:// www.ubishops.ca/BaudrillardStudies)

. 2006b. "Virtuality and Events: The Hell of Power." International Journal of Baudrillard Studies (July). (http:// www.ubishops.ca/BaudrillardStudies)

.2007. "The Global and Universal." The European Graduate School. (http://www.egs.edu)
Baudrillard, Jean and Truls, Lie. 2007. "The Art of Disappearing." Eurozine (March 4). (http://www.eurozine.com)

Bayard, Caroline and Graham Knight. 1995. "Vivsecting the 90s: An Interview with Jean Baudrillard." CTheory (March 8). (http://www.ctheory.net)

Benjamin, Marina. 1997. “The Philosopher Clown.” Prospect 21 (July). (http://www.prospect-magizine.co.uk)

Blackburn, Simon. 2007. “Au Revoir Baudrillard.” Prospect Magazine 133 (April)(http://www.prospect-magazine.co.uk)

Bloom, Allan. 1987. The Closing of the American Mind. New York: Simon \& Schuster

Chan, Evan 2001. "Against Postmodernism etcetera- A Conversation with Susan Sontag." Postmodern Culture 12 (1). (http://muse.jhu.edu/journals/pmc)

Cohen, Patricia. 2007. "Jean Baudrillard, 77, Critic and Prolific Author." The New York Times (March 7). (http://www. nytimes.com)

Coulter, Gerry. 2004. "Reversibility: Baudrillard's ‘One Great Thought." International Journal of Baudrillard Studies (July). (http://www.ubishops.ca/BaudrillardStudies)

. 2005. "Passings: Cool Memories of Susan Sontag: An American Intellectual." International Journal of Baudrillard Studies (July). (http://www.ubishops.ca/BaudrillardStudies)

Donadio, Rachel. 2007. “Essay: Revisiting the Canon Wars.”The New York Times (September 16). (http://www.nytimes.com)

Frankfurt, Harry G. 2005. On Bullshit. Princeton, NJ and Oxford, U.K.: Princeton University Press

Friedman, Thomas L. 2000. The Lexus and the Olive Tree. New York: Anchor Books

Fukuyama, Francis. 1992. The End of History and the Last Man. London and New York: Penguin Books

Gitlin, Todd. 1995. The Twilight of Common Dreams; Why America is Wracked by Culture Wars. New York: Metropolitan Books

Harkin, James. 2007. "Has this Man Really Died?” Guardian (March 8). (http://www.guardian.co.uk)

Heidegger, Martin. 1977. The Question Concerning Technology and Other Essays, trans. by William Lovitt. New York: Harper Torchbooks

Herman, David. 2005. “Thinking Globally.” Prospect Magazine 115 (October). (http://www.prospect-magazine.co.uk)

International Herald Tribune [Europe]. 2007. "French Philosopher Jean Baudrillard Dies." (March, 6). (http://www. iht.com)

Kellner, Douglas. 1989. Jean Baudrillard: From Marxism to Postmodernism and Beyond. Cambridge, UK: Polity Press 
. 2005a [revised 2007]. "Jean Baudrillard.” Stanford Encyclopedia of Philosophy. (http://plato.stanford.edu)

2005b. "Baudrillard, Globalization and Terrorism: Some Comments on Recent Adventures of the Image and Spectacle on Baudrillard's 75th Birthday." International Journal of Baudrillard Studies (January). (http://www.ubishops.ca/ BaudrillardStudies)

. 2006. "Jean Baudrillard After Modernity: On A Provocateur and Challenger." International Journal of Baudrillard Studies (January). (http://www.ubishops.ca/ BaudrillardStudies)

. 2007. "Remembering Baudrillard: A Good Long Run." International Journal of Baudrillard Studies (March 11). (http://www.ubishops.ca/BaudrillardStudies)

Kroker, Arthur. 2002. "Hyper-Heidegger." CTheory. (http://www. ctheory.net)

2004. The Will to Technology and Culture of Nihilism: Heidegger, Marx, and Nietzsche. Toronto: University of Toronto

.2007. "The Spirit of Jean Baudrillard: In Memorium:19292007. 1000 Days of Theory CTheory. (March 7). (http://www. ctheory.net)

Leith, Sam. 2007. "Notebook: One of These Comic Heros is Really Dead."The Daily Telegraph (March 12): 22

Libération. 2007. "Décès de Jean Baudrillard, pourfendeur de la société de consommation et des médias." (March 6). (http:// www.liberation.fr).

MacFarquhar, Larissa. 2005. "Baudrillard on Tour." The New Yorker (November 28). (http://www.newyorker.com)

Poole, Steven. 2007. "Jean Baudrillard: Philosopher and Sociologist who Blurred the Boundaries between Reality and Simulation." Guardian Unlimited (March 7, 2007) (http:// books.guardian.co.uk)

Reuters. 2007. "Postmodern French Philosopher Jean Baudrillard Dies." (March 7). (http://www.reuters.com)
Rorty, Richard. 1989. Contingency, Irony, and Solidarity: Philosophical Papers, Vol. 1. Cambridge, UK and New York: Cambridge University Press

Sokal, Alan. 1996. "A Physicist Experiments with Cultural Studies.” Lingua Franca (May 1996). (http://www.physics. nyu.edu/faculty/sokal)

Sokal, Alan and Jean Bricmont. 1998. Fashionable Nonsense: Postmodern Intellectuals' Abuse of Science. New York: Picador

Solomon, Deborah. 2005. "Questions for Jean Baudrillard: Continental Drift" The New York Times (November 20). (http://www.nytimes.com)

The Economist. 2007. “John Baudrillard. (March 15). (http:// www.economist.com)

The New York Times. 1997. "Think Tank: Lofty Ideas that May be Losing Altitude.” (November 1, 1997). (http://www. nytimes.com)

The Times. 2007. “Jean Baudrillard.” (March 7). (http://www. timesonline.co.uk)

Turner, Chris. 2007. "Jean Baudrillard: Striking Against Banality. The Drawbridge (5). (http://www.thedrawbridge.org.uk)

Wolin, Richard. 1990. The Politics of Being: The Political Thought of Martin Heidegger. New York: Columbia University Press

.2002."September 11 and the Self-Castigating Left." South Central Review (19:2/3): 39-49

2004. The Seduction of Unreason: The Intellectual Romance with Fascism From Nietzsche to Postmodernism. Princeton, NJ and Oxford, UK: Princeton University Press

Woo, Elaine. 2007. "Jean Baudrillard, 77; Kept Sharp Eye on Blurry Reality." Los Angeles Times (March 11). (http://www. latimes.com) 
